\title{
Experimental Investigation of Chaos in Input Regulated Solar PV Powered Cuk Converter
}

\author{
M.Vaigundamoorthi \\ Faculty, Anand Institute of Higher Technology \\ Chennai -603103, India.
}

\author{
R.Ramesh \\ Assistant Professor, CEG, Anna University \\ Chennai -6000025, India
}

\begin{abstract}
This experimental study deals with the investigation of chaos during the regulation of output voltage of solar photovoltaic module. The Cuk converter is used as an interface between solar PV module and load, since the Cuk converter is the good choice for the maximum power point tracking (MPPT) circuits. The input voltage of the converter is controlled in order to regulate the operating point of the solar PV module. This paper proposes to design PID controller to obtain the input voltage of the converter is chaotic free and regulated one. The PID controller improves the transient response on the input voltage of the converter, avoids oscillation, overshoot, making easier the functioning of MPPT methods and ensures period -1 operation.
\end{abstract}

\section{General terms}

Analyze, verification

\section{Key words}

Solar PV module, Cuk converter, chaos, PID controller, voltage regulation

\section{INTRODUCTION}

Solar energy which is free and abundant in most parts of the world has proven to be a challenging source of energy in many developing and developed countries. Solar PV power systems can be operated as a standalone, hybrid or grid connected systems. The solar PV cell has a nonlinear $V-I$ and $P-V$ characteristics [1-2], which depend on the irradiance, operating temperature and load condition of the cell. The output voltage of the solar PV module consist non linearity including quasiperiodicity and chaos due to its non linear characteristics. The solar power system is designed to operate the solar PV module at maximum power point using DC-DC converter.

The DC-DC converter is connected between a solar panel and a load or battery bus, is a pulse width modulated (PWM) $\mathrm{dc} / \mathrm{dc}$ Cuk converter[3-6] or their derived circuits is used to extract maximum power from solar PV panel. Hence, by adjusting the nominal duty cycle of the main switch of Cuk converter, the input resistance can be made equal to the equivalent output resistance of the solar PV panel and ensures the maximum power transfer. To enhance the conversion efficiency, and to improve the transient response, the ZVS- PWM Active Clamp Cuk converter is analyzed and designed in [7] without input voltage regulation. The PV array operating point can be adjusted by regulating the voltage or current at the terminals of the module. The voltage control is preferred because the voltage at the MPP is approximately constant. The PV current, on the other hand, changes greatly when the solar irradiation varies. Input voltage regulation for PV powered buck converter is proposed in [8-9] using PI compensator. Also this work proposes three types of control strategies and closed loop stability were investigated. The controllers were optimized to operate at the nominal MPP of the PV device.
DC-DC converters exhibit different non-linear phenomena including bifurcations, quasi-periodicity and chaos under both voltage mode and current mode control schemes [10-12]. Due to the non linear dynamics in the power electronic circuits, their operation is characterized by the cyclic switching of circuit topologies, which gives rise to a variety of chaotic behavior [1012]. Hence all the power dc-dc converters used for solar PV power system is designed to operate period -1 operation in which all the waveforms repeat at the same rate as the driving clock. This paper discussed above control problem which is shown in Fig.1. The PV array feeds the DC-DC Cuk converter. The Cuk converter serves as an interface between the PV array and the load.

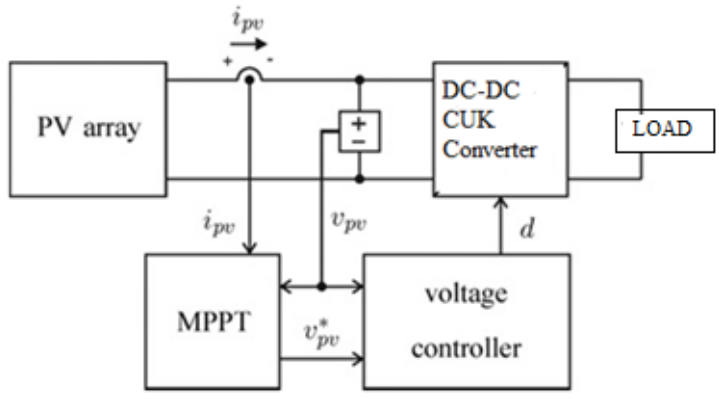

Fig .1: Input-regulated converter interfaces the PV array with the load

A feedback controller with a proportional, integral and derivative (PID) controller for regulating the converter voltage is preferred. Besides reducing losses and stress due to the bandwidth-limited regulation of the duty cycle, the presence of PID controller improves the transient response on the input voltage of the Cuk converter and avoids oscillation and overshoot, making easier the functioning of MPPT methods.

This paper proposes to design PID controller to regulate the input voltage of solar PV powered Cuk converter and to operate in only one type of periodic operation, commonly known as "period-1 operation" in which all the waveforms repeat at the same rate as the driving clock under all possible disturbances.

\section{LINEARIZATION OF SOLAR -L1235- 37W PV MODULE AT MPP}

A solar cell is a kind of p-n junction semiconductor device and converts light energy into electrical energy. The output characteristics of the solar PV module depend on the irradiance and the operating temperature of the cell. Solar PV module of L1235-37Wp has non linear V-I charecteristics which is shown in Fig. 2.The equation of the V-I characteristics is $[1,2]$

$\mathrm{i}_{\mathrm{pv}}=\mathrm{I}_{\mathrm{pv}}-\mathrm{I}_{\mathrm{o}}\left[\exp \left(\frac{V_{P V}+R_{S} I_{p v}}{V_{\mathrm{b} * \mathrm{a}}}\right)-1\right]-\frac{V_{p v}+R_{S} \mathbb{I}_{p v}}{R_{P}}$

$I_{p v-}$ short circuit current; $I_{0}$ - diode saturation current, 
$\mathrm{V}_{\mathrm{t}}=\mathrm{Ns} \mathrm{K} \mathrm{T/q}$ is the thermal voltage with Ns cells connected in series, $R_{s}$ is the equivalent series resistance, $R_{p}$ is the equivalent shunt resistance and $\mathrm{a}$ is the ideality constant. The table I shows the parameters of L1235-37Wp solar PV module.

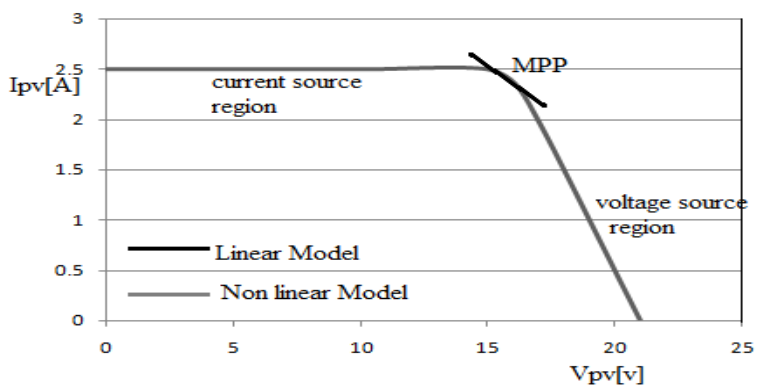

Fig.2: Non linear V-I characteristics of L1235-37Wp solar module

Table 1. Specification of L1235-37W solar PV module

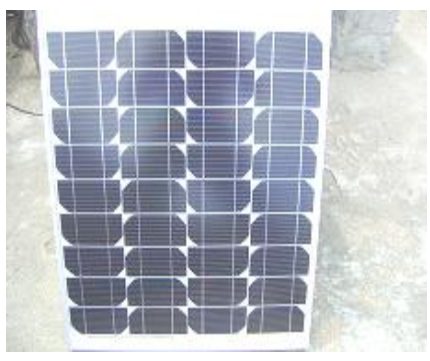

Fig.2.a:L1235-37W solar panel under test

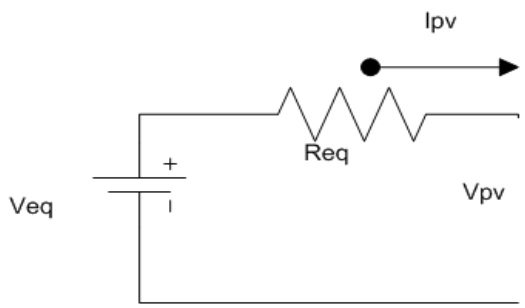

Fig.3: Linear equivalent circuit valid at the linearization Point

The linear equivalent circuit of Fig.3 is valid at the linearization point $(\mathrm{V}, \mathrm{I})$ and is a good approximation of the solar PV module for the computer simulation [2]. The dynamic behavior of the solar PV powered Cuk converter system depends strongly on the point of operation of the module.

\section{DESIGN OF POWER CIRCUIT}

Cuk converter provides an output voltage which is less than or greater than the input voltage. It works based on the capacitor energy transfer. It has low switching losses and highest efficiency among all non-isolated DC-DC converters. It exhibits non pulsating input current characteristic due to the inductor in the input stage. Also Cuk converter is capable of sweeping the V-I curve of solar PV module in CCM from open circuit voltage to short circuit current condition and hence Cuk converter is a suitable converter to be employed in designing the MPPT circuits. Cuk converter which used as the power stage interface between PV module and the load. Cuk converter has two modes of operation. First mode of operation is when the switch (MOSFET) is closed (ON) and it is conducting as a short circuit. In this mode, the current through inductor L1 rises. At the same time, the voltage of capacitor $\mathrm{C} 1$ reverse biases diode $\mathrm{D}$ and turns it off. The capacitor $\left(\mathrm{C}_{1}\right)$ releases its stored energy to the load

[6].

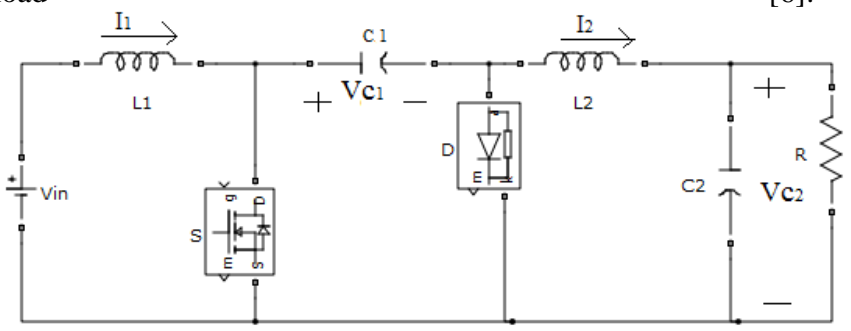

Fig.4.a. Cuk converter used as the solar PV power stage interface

\begin{tabular}{|l|l|}
\hline Maximum power at MPP $\left(\mathrm{P}_{\max }\right)$ & $37 \mathrm{~W}$ \\
\hline Short circuit current $\left(\mathrm{I}_{\mathrm{sc}}\right)$ & $2.5 \mathrm{~A}$ \\
\hline Voltage at $\mathrm{MPP}\left(\mathrm{V}_{\mathrm{pv}}\right)$ & 16.4 \\
\hline Current at MPP $\left(\mathrm{I}_{\mathrm{pv}}\right)$ & 2.25 \\
\hline Thevenin's equivalent voltage $\left(\mathrm{V}_{\mathrm{eq}}\right)$ & $34.6 \mathrm{~V}$ \\
\hline Equivalent resistance $\left(\mathrm{R}_{\mathrm{eq}}\right)$ & $7.289 \Omega$ \\
\hline Open circuit voltage $\left(\mathrm{V}_{\mathrm{oc}}\right)$ & $21 \mathrm{~V}$ \\
\hline
\end{tabular}

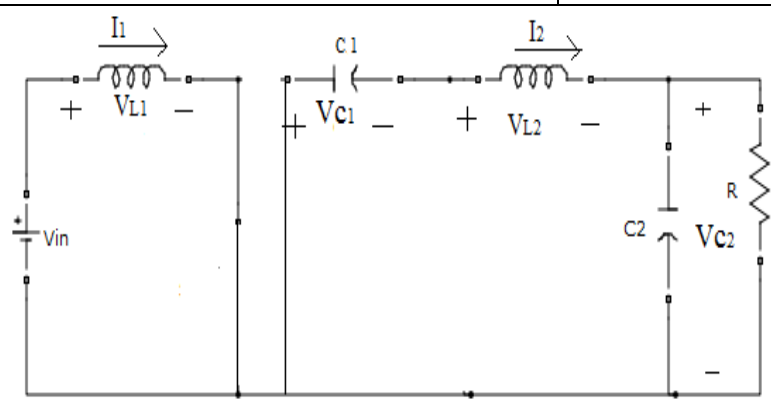

(a)

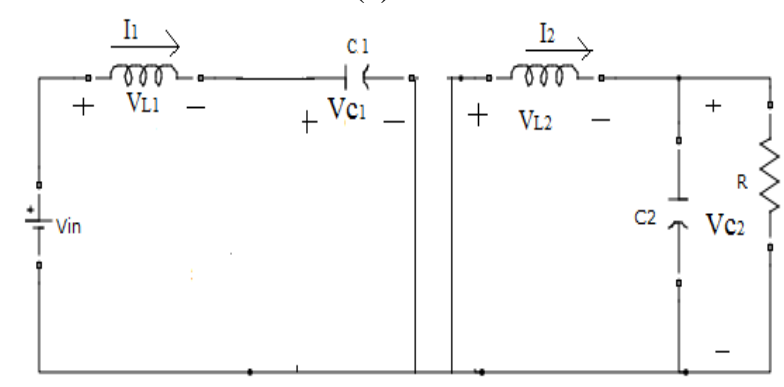

(b)

Fig.6:Cuk converter with (a) switch ON and (b) switch OFF On the second operating mode when the $\operatorname{switch}(\mathrm{S})$ is open (OFF), diode (D) is forward biased and conducting energy to the output. Capacitor $\mathrm{C} 1$ is charging from input supply and the energy stored in the inductor L2 is transferred to the load. The diode $\mathrm{D}$ and switch (S) provide a synchronous switching action.

The relation between input and output currents and voltage are given by

$$
\frac{V_{I N}}{V_{D}}=-\frac{D}{(1-D)}
$$




$$
\frac{\mathrm{I}_{\mathrm{IN}}}{\mathrm{I}_{0}}=-\frac{\mathrm{D}}{\left(\mathbb{1}-\mathrm{D}_{\mathrm{D}}\right.}
$$

The table.2 shows the components used in simulation and hardware setup for the power circuit.

Table 2. Specification of Cuk converter

\begin{tabular}{|l|l|}
\hline Input inductor L1 & $500 \mathrm{e}-6 \mathrm{H}$ \\
\hline Filter inductor L2 & $500 \mathrm{e}-6 \mathrm{H}$ \\
\hline Capacitor C1 & $220 \mathrm{e}-6 \mathrm{~F}$ \\
\hline Filter capacitor C2 & $220 \mathrm{e}-6 \mathrm{~F}$ \\
\hline Resistive load R & $2 \Omega$ \\
\hline Switching frequency & $25 \mathrm{kHz}$ \\
\hline Switch : MOSFET & IRF840 \\
\hline Optocoupler & MCT2E \\
\hline Diode & MUR450 \\
\hline
\end{tabular}

The input voltage regulation of the converter is carried out using PID controller. The solar PV powered Cuk converter system consists of a solar PV module, Cuk converter and gate drive, control of switch(S) is carried out using the control circuit. The control task involves the measuring the solar PV module output voltage and it has been compared with reference voltage using opamp based comparator. Based on the error from the comparator, the PID controller is designed in such a way that PWM gate pulse is generated using 555 IC to control the switching of MOSFET. This process will ensure the converter input voltage regulation. During the implementation and selection of resistance, capacitance values for P, PI, PID controllers, the solar PV module output voltage ripple is analyzed experimentally.

\section{SIMULATION RESULT}

The diagram of the input regulated closed loop system designed in Matlab/Simulink is presented in Fig.7 that include linearised model of solar PV array which consists of voltage source in series with the equivalent panel resistance, Cuk converter, PID controller. To test the system operation, condition of changing irradiation is modeled in which indent to change the solar panel resistance. Initially the solar panel resistance is kept as $7.289 \Omega$ which corresponds to irradiation of $1000 \mathrm{~W} / \mathrm{m}^{\wedge} 2$. At $\mathrm{t}=0.5 \mathrm{sec}$, the panel resistance is reduced by $50 \%$ which corresponds to $500 \mathrm{~W} / \mathrm{m}^{\wedge} 2$. The PID controller is designed in such a way that, converter input voltage regulation of $16.4 \mathrm{~V}$ is achieved for both the conditions

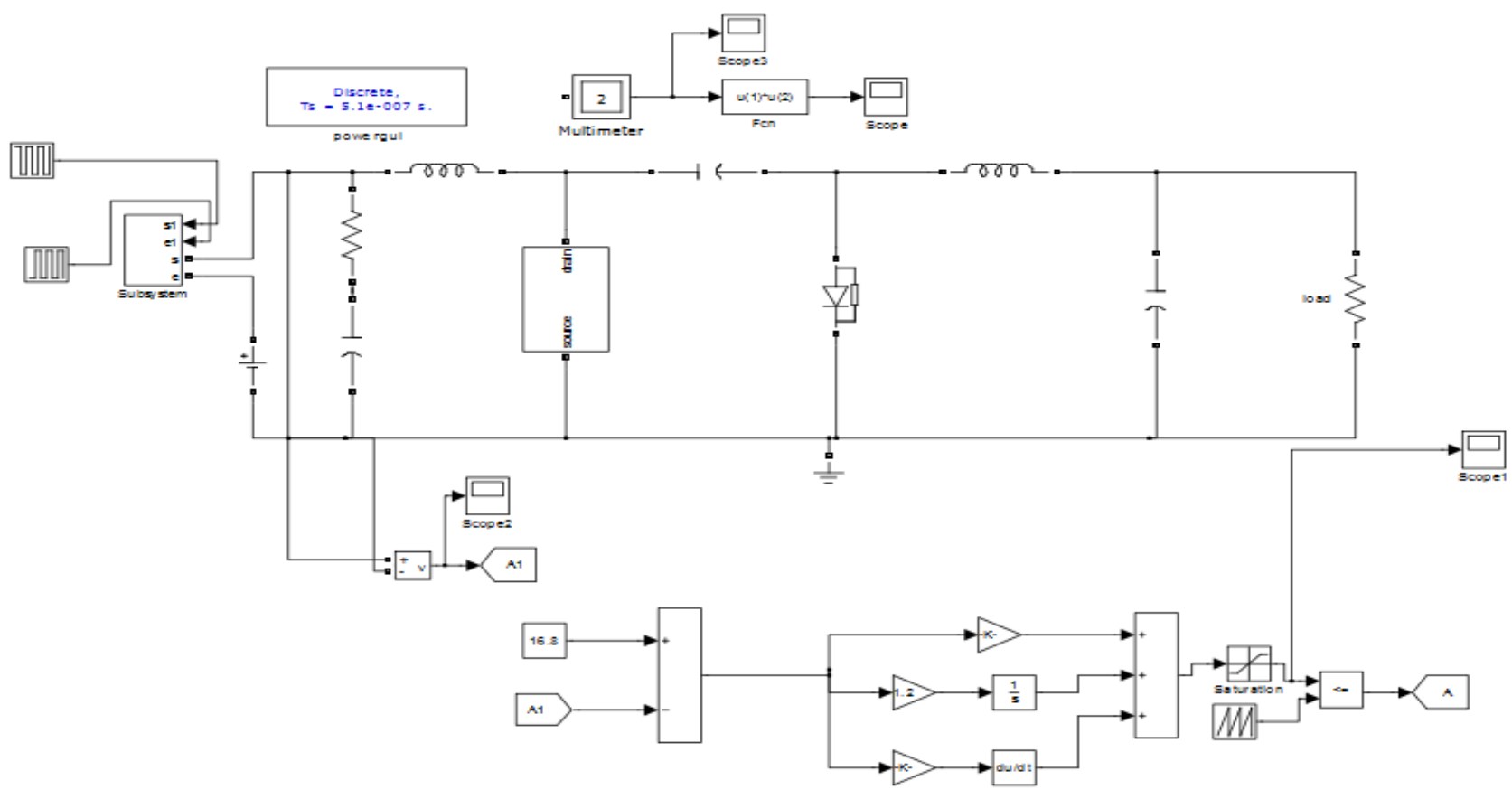

Fig.7: Diagram of the closed loop system for input voltage regulation of solar PV powered Cuk converter

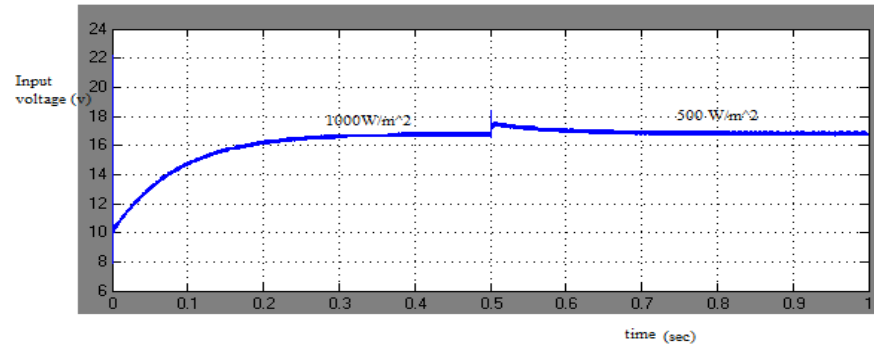

Fig.8: Input voltage regulation due to the change in irradiation level

\section{EXPERIMENTAL SETUP}

The block diagram of the experimental setup is shown in fig.9. It consists of a power circuit and a control circuit. The power circuit consists of inductors $L 1$ and $L 2$ made of ferrite core, and capacitors $C 1$ and $C 2$ are of plain polyester. Power MOSFETs IRF840 is used as active switch $S$. The converter is assumed to 
operate in continuous conduction mode. The control circuit consists of the following blocks: voltage divider, $V_{\text {ref }}$ generation, difference amplifier, inverting amplifier, and a Schmitt trigger. A reference voltage is generated and fed to noninverting input of the difference amplifier.

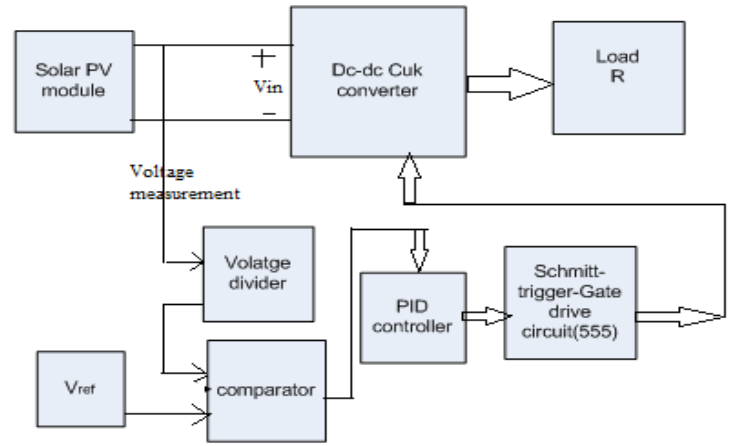

Fig.9:Block diagram of the experimental setup

Voltage measurement is required at the point where the solar PV module output is connected to the input of Cuk converter. The voltage at this point is the operating voltage of the PV module. The voltage from the divider circuit is given to the inverting input of the difference amplifier LM358. This input voltage is regulated irrespective of the temperature and irradiation change. During the regulation of input voltage of Cuk converter using $\mathrm{P}$, PI, PID controllers, the input voltage ripple of the Cuk converter is analyzed experimentally. It is found that, there is a chaotic non-literality is present in the input voltage when P, PI controllers are used to regulate the input voltage. Period -1 operation is ensured when PID controller is used to regulate the input voltage of the converter.

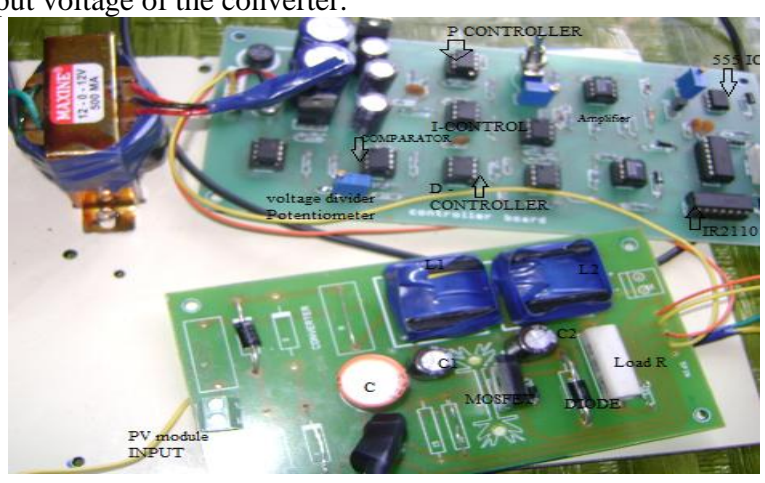

Fig.10: Photography of an experimental setup.

The input voltage solar PV powered Cuk converter is measured without controller which is shown in Fig.11.The converter unregulated input voltage takes $30 \mathrm{~ms}$ to reach steady state value of $15.6 \mathrm{~V}$. But the converter regulated input voltage is built up in $8 \mathrm{~ms}$ as shown in Fig .12 when PID controller is used.

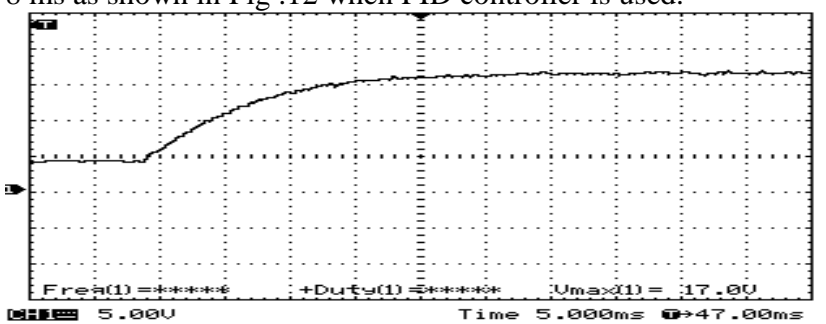

Fig.11: Converter unregulated input voltage without controllers

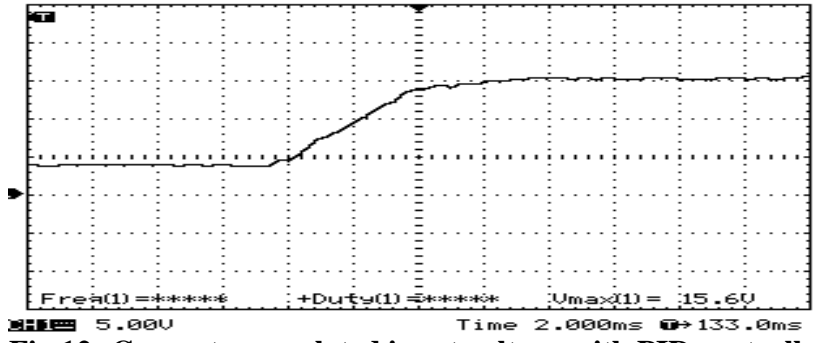

Fig.12: Converter regulated input voltage with PID controller

\subsection{Experimental analysis of solar $P V$ powered Cuk converter Input voltage regulation using P-controller}

The input voltage of the solar PV module fed Cuk converter is regulated using P-controller. The feedback resistance $=10 \mathrm{k} \Omega$, input resistance $=1 \mathrm{k} \Omega$ are selected. The regulated Cuk converter input voltage ripple is experimentally analyzed. The fundamental Period 1- waveform has been found with $\mathrm{V}_{\text {ref }}=5.68 \mathrm{~V}$. The solar powered Cuk converter system has stable periodic behavior. The input voltage of the period-1 operation is shown in fig 11.1 . When the reference is $5.2 \mathrm{~V}$, the system has unstable periodic behavior. The input voltage of the period -2 operation is shown in fig 11.2. Varying $\mathrm{V}_{\text {ref }}$ further, the system input voltage has unstable aperiodic behavior. Chaotic waveform is observed for the $\mathrm{V}_{\text {ref }}=4.8 \mathrm{~V}$ as shown in fig. 11.3

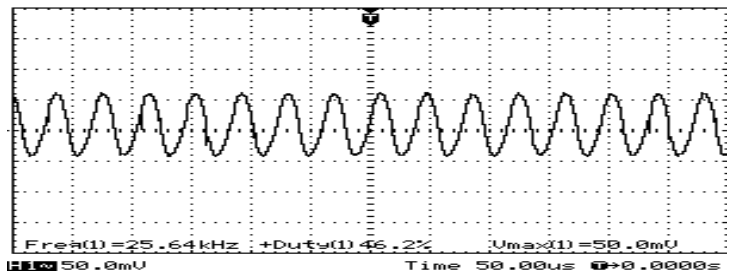

Fig.11.1: Experimental Period-1 waveform in the input voltage when $V_{\text {ref }}=5.68 \mathrm{~V}$

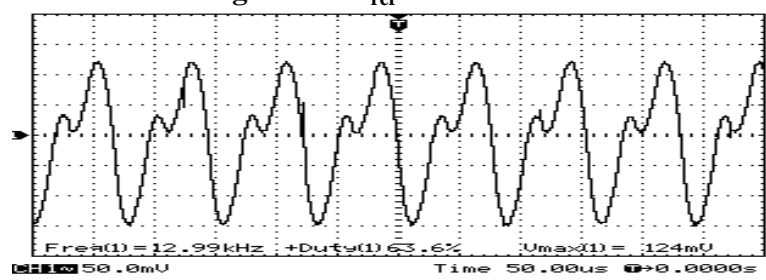

Fig .11.2.Experimental Period -2 waveform when $V_{\text {ref }}=5.2 \mathrm{~V}$

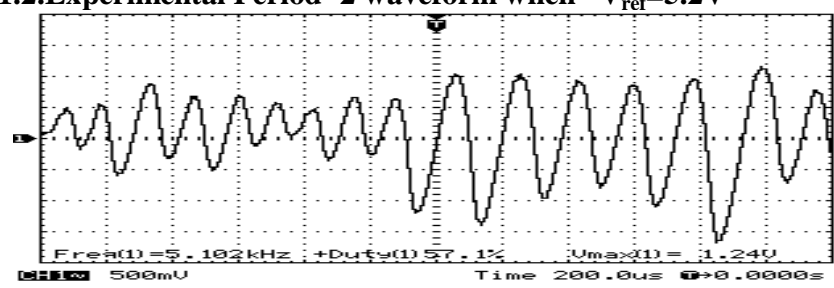

Fig.11.3: Experimental chaos waveform when $V_{\text {ref }}=4.8 \mathrm{~V}$

\subsection{Experimental analysis of solar $P V$ powered Cuk converter input voltage regulation with PI controller}

The input voltage of the solar PV module fed Cuk converter is regulated using PI-controller. The feedback resistance $=10 \mathrm{k} \Omega$, input resistance $=1 \mathrm{k} \Omega$ are selected for P- controller and feedback capacitor $=0.1 \mu \mathrm{F}, \mathrm{R}_{\mathrm{i}}=1 \mathrm{k} \Omega$ are selected for I-controller. The 
input voltage of the Cuk converter is regulated and its ripple is experimentally analyzed. The PI controller improves the transient response of the input voltage. The time taken to reach the regulated input voltage is $10 \mathrm{~ms}$. The fundamental period -1 waveform shown in fig 12.1 has been found with $\mathrm{V}_{\text {ref }}=5.68 \mathrm{~V}$. But the converter reference voltage is decreased as $\mathrm{V}_{\text {ref }}=4.8 \mathrm{~V}$, chaotic unstable behavior is observed as shown fig.12.2. The input gate pulse to switch(S) corresponds unstable chaotic mode is shown in fig. 12.3

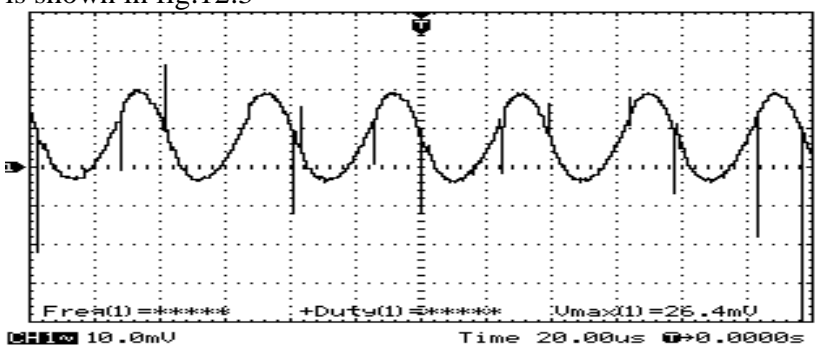

Fig.12.1. Experimental stable Period-1 waveform when $\mathrm{V}_{\text {ref }}=\mathbf{5 . 6 8 \mathrm { V }}$

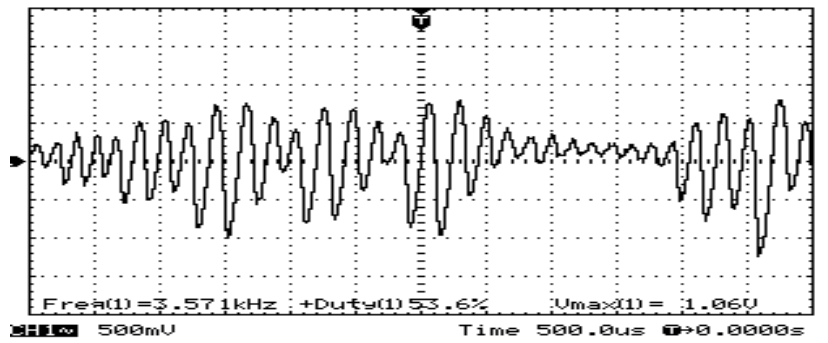

Fig .12.2.Experimental unstable chaotic waveform when

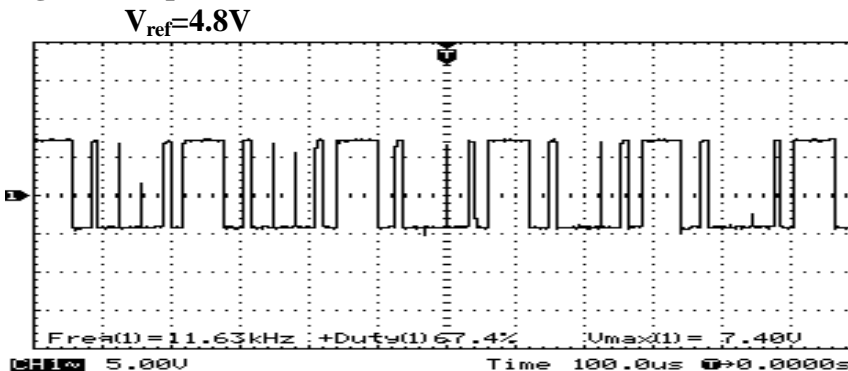

Fig.12.3.Gate pulse to switch - during the chaos mode of operation with PI controller

\subsection{Experimental analysis of solar PV powered Cuk converter input voltage regulation with PID controller}

The input voltage of the solar PV module fed Cuk converter is regulated using PID-controller which is shown in Fig.13. The feedback resistance $=10 \mathrm{k} \Omega$, input resistance $=1 \mathrm{k} \Omega$ are selected for P- controller and feedback capacitor $=0.1 \mu \mathrm{F}$, input resistance $\mathrm{R}_{\mathrm{i}}=1 \mathrm{k} \Omega$ are selected for I-controller. Input series resistance $\mathrm{R}_{\mathrm{se}}=22 \Omega$ input capacitor $\mathrm{C}_{\mathrm{d}}=0.1 \mu \mathrm{F}$, feedback resistance $\mathrm{R}_{\mathrm{d}}=10 \mathrm{k} \Omega$ are selected for $\mathrm{D}$ controller. The input voltage is regulated and the ripple is experimentally analyzed for the supply disturbances. The $\mathrm{V}_{\text {ref }}$ is varied from $4.00 \mathrm{~V}$ to $5.76 \mathrm{~V}$ and observed that, the converter is always operated in period -1 stable region for all the parameter variations which is given in fig 14. Also the PID controller improves the transient response of the input voltage of the Cuk converter. The time taken for the input voltage of the converter to reach the regulated voltage value is $10 \mathrm{milli}$ sec. The gate pulse corresponds to input voltage regulation of Cuk converter with PID controller is shown in fig. 15

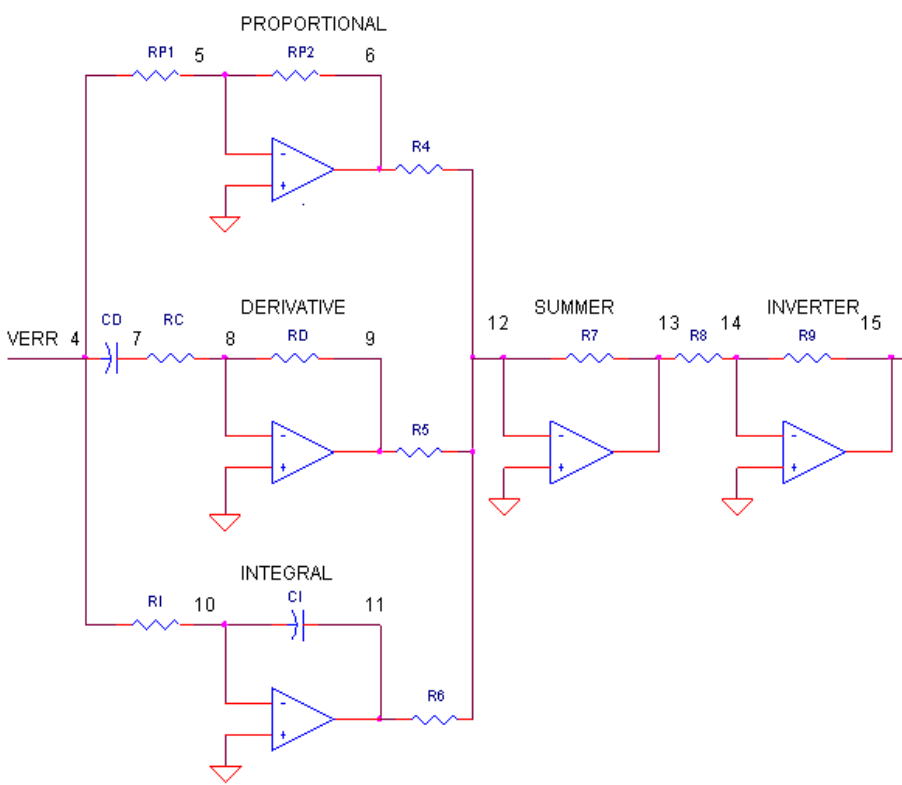

Fig.13: Diagram of the PID controller

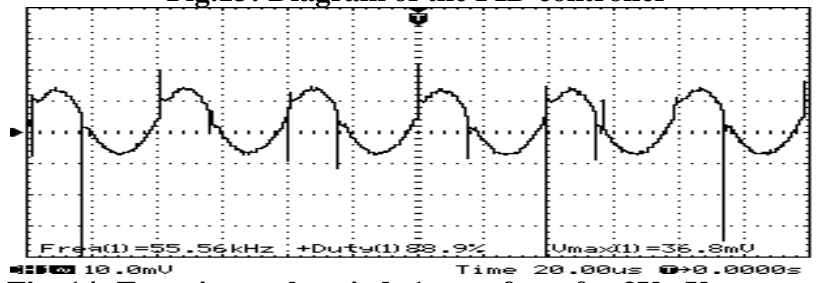

Fig .14: Experimental period -1 waveform for $3 \mathrm{~V}<\mathrm{V}_{\text {ref }}<$

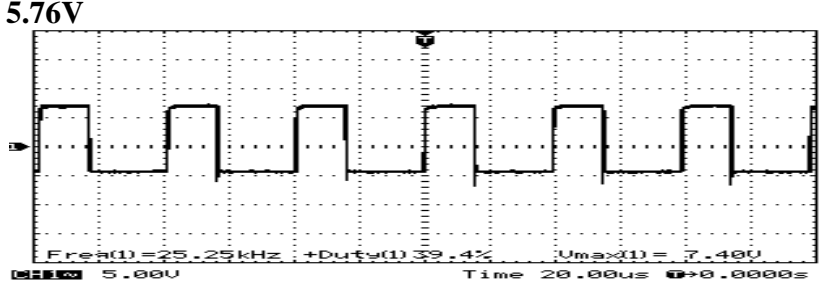

Fig.15: Gate pulse to switch(S) - during the Period -1 mode of operation with PID controller

\section{CONCLUSION}

The control approaches developed in this paper is intended for the control of the input voltage of the Cuk converter. The input voltage of the converter is controlled in order to control the solar PV module output voltage. This paper proposed to design P,PI ,PID controllers to regulate the input voltage of Cuk converter and concluded that to operate the PV powered Cuk converter at chaos free "period-1 operation" in which all the waveforms repeat at the same rate as the driving clock,PID controller is the good choice for the parameter variations.

\section{REFERENCES}

[1] Villalva.M.G, Gazoli J.R., and Ruppert E.F, 'Modeling and circuit-based simulation of photovoltaic arrays', Revista Eletro^nica de Potência (SOBRAEP), Brazilian J. Power,Electron., 2009, 14, pp. 35-45

[2] Villalva.M.G, Gazoli J.R., and Ruppert E.F, 'Comprehensive approach to modeling and simulation of photovoltaic arrays',IEEE Trans. Power Electron., 2009, 25, (5), pp. 1198-1208

[3] Tse,K.K., Ho,M.T., Henry S.-H., Chung., Ron Hui,S.Y, “A Novel Maximum Power Point Tracker for PV Panels 
Using Switching Frequency Modulation"IEEE transactions on power electronics, vol. 17, no. 6 , November 2002 pp .980-989

[4] Henry Shu-Hung Chung., Tse,K.K., Ron Hui,S.Y., Mok,C.M.,Ho,M.T, “A Novel Maximum Power Point Tracking Technique for Solar Panels Using a SEPIC or Cuk Converter" IEEE transactions on power electronics, vol. 18 , no. 3, may 2003 ,pp.717-724

[5] Tse,K.K., Billy, M. T., Ho, Henry Shu-Hung Chung, Ron Hui,S.Y, “ A Comparative Study of Maximum-PowerPoint Trackers for Photovoltaic Panels Using SwitchingFrequency Modulation Scheme" IEEE transactions on industrial electronics, vol. 51, no. 2, April 2004,PP..410418

[6] Azadeh Safari and Saad Mekhilef, "Simulation and Hardware Implementation of Incremental Conductance MPPT With Direct Control Method Using Cuk Converter" IEEE transactions on industrial electronics, vol. 58, no. 4, April 2011,pp.1154-1161

[7] Vaigundamoorthi.M and Ramesh.R, "ZVS-PWM Active clamping modified cuk converter based MPPT for solar PV modules "European Journal of Scientific Research, Vol.58 No.3 (2011), pp.305-315
[8] Villalva.M.G, de SiqueiraT.G and Ruppert.E, "voltage regulation of photovoltaic arrays: small signal analysis and controller design” IET Power Electron., 2010, Vol. 3, Iss. 6, pp. 869-880

[9] Villalva.M.G , and Ruppert.E, "Dynamic analysis of the input controlled buck converter fed by a photovoltaic array" Revista Controle \& Automação/Vol.19 no.4/Outubro, Novembro e Dezembro 2008,pp 463-474

[10]Sajid Iqbal, Masood Ahmed, and Suhail Aftab Qureshi "Investigation of chaos behavior in dc-dc converter" World Academy of Science, Engineering and Technology 33 2007,pp-291-294

[11] Mario di Bernardo, Franco Garofalo, Luigi Glielmo, and Francesco Vasca, "Switchings, Bifurcations, and Chaos in DC/DC Converters" IEEE transactions on circuits and systems-I: fundamental theory and applications, vol. 45, no. 2, february 1998,pp-133-141

[12]Kavitha.A, Uma.G "Control of chaos in sepic dc-dc converter" International Journal of Control, Automation, and Systems (2010) 8(6):1320-1329 